\title{
The Influence of Plankton on the Phosphate Content of Stored Sea-Water.
}

\author{
$\mathrm{By}$ \\ By Robert Gill, M.Sc., \\ Biochemist, Dove Marine Laboratory, Cullercoats.
}

With 2 Figures in the Text.

THE possibility of a sample of sea-water, untreated and unfiltered, suffering change in its soluble phosphate concentration during storage is well recognised. Matthews (1917) observes that "if the sample is allowed to stand without previous sterilisation the phosphates decrease and may be entirely removed in a few weeks." Atkins (1923) gives actual figures in illustration of this decrease with reference to insolated sea-water, though he also states " that open sea-water stored in the dark in bottles used for chloride samples, appears to undergo but little change for a couple of weeks in spring." He exposed sea-water to a strong light, and found that the original phosphate concentration, of about $40 \mathrm{mgms} . \mathrm{P}_{2} \mathrm{O}_{5}$ per cubic metre, decreased to the order of 2 to $3 \mathrm{mgms}$; the rapidity of the decrease being greatest in the spring months. The elimination of soluble phosphate in this way is ascribed to the uptake of this essential plant food by organisms during the process of their growth and multiplication, and continues until practically no available phosphate remains.

Atkins (1925), in a later paper, refers to increases in soluble phosphate observed in stored sea-water. These increases are undoubtedly due to the death of organisms originally present, and, by bacterial or other action, the subsequent dissolution of their bodies, although in some instances such increases on storage have been traced to enrichment of the sample by the glass of the bottle, more especially where soft white glass is used (Atkins, 1926). Numerous published analyses, it is clear, are erroneous owing to this decomposition, the error being more appreciable the longer the interval between collection of the sample and analysis. Atkins (1925, p. 716) cites a case in point. A series of samples from surface down to 775 metres was taken from the deep water N.E. of the Wyville-Thomson ridge on August 8, 1924, and analysed September 
3, 1924, nearly four weeks elapsing between the two operations. The following values were obtained :-

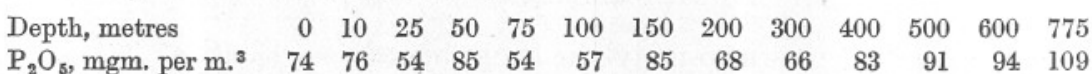

The values for the upper layers were all extraordinarily high, surface and 10 metres depth giving 74 and 76 mgms. $\mathrm{P}_{2} \mathrm{O}_{5}$ per $\mathrm{m} \cdot{ }^{3}$ respectively ; and no regular gradient was observed as usually obtains in the summer months from surface to bottom. One of the reasons advanced for the explanation of these puzzling and irregular results was the leakage of phosphate from the white glass sample bottles, and it was later discovered (Atkins, 1926, p. 448) that similar bottles did, in fact, yield phosphate to distilled water. But from the data put forward below it would appear that the real cause resided in greater part in the decomposition of organisms originally present in the samples.

Fig. 1.

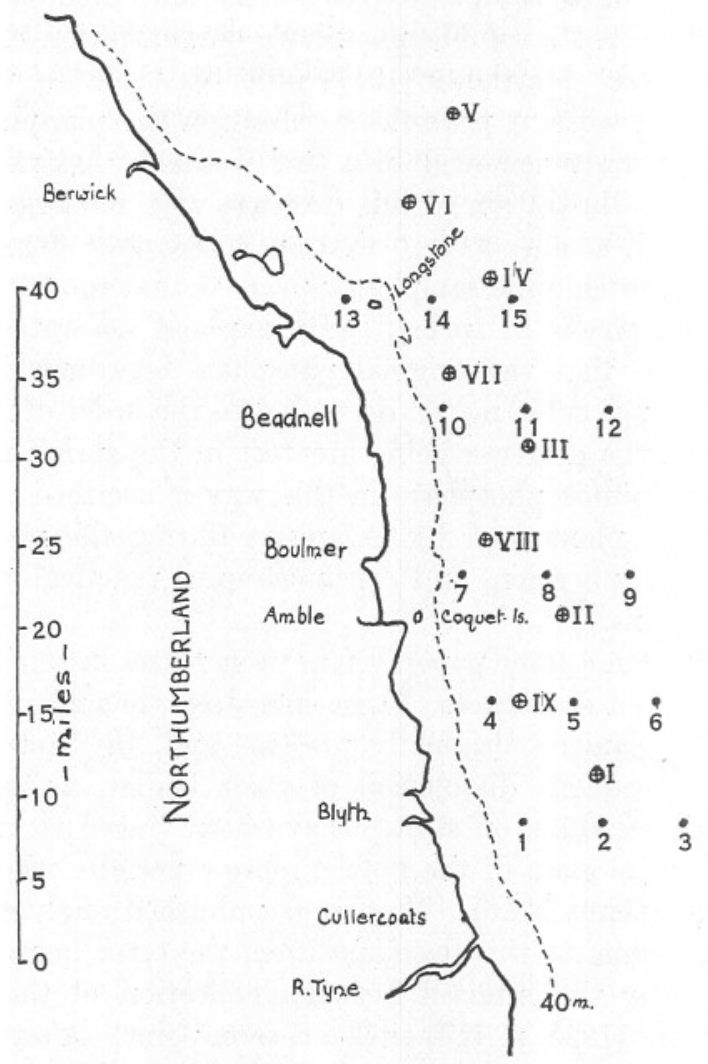

Fig. 1.-Hydrographical Stations off Northumberland Coast, Nos. 1-15. Plankton Stations, Nos, I-IX. 


\section{Phosphate Content of North Sea Water off NoRThumberland CoAst.}

Employing the cœruleo-molybdic colorimetric method of Denigès (1921) for the estimation of phosphate in sea-water, as elaborated by Atkins (1923, p. 144 ; 1925, p. 719), periodical observations have been performed in the North Sea off the Northumberland coast. The attached chart (Fig. 1) indicates the positions of the fifteen stations worked.

The results of a cruise in July, 1926, were abnormally high and erratic, and pointed to considerable alteration having occurred in the samples during the storage period between collection and analysis, which was unduly prolonged. It was determined to trace this change in the samples of a later cruise.

This following cruise was made on September 23rd to 25th, 1926, when all stations were visited and sampled at each 10 metres depth from surface to bottom. The phosphate content of each sample was first determined on October 4th to 6th, about eleven days after collection, the bottles having been stored in the dark during this period. It is highly desirable that phosphates should be determined as soon as possible after collection of the samples, and the results obtained after eleven days' delay probably do not give the initial values. Table I below gives the results obtained, together with mean values at each depth and each station over the area:-

\section{TABLE I.}

Phosphate, Mg. Per M. ${ }^{3}$, at Stations $1-15$ off the Northumberland Coast. Samples taken September 23Rd to 25th, 1926, analysed OCTOBER 4TH To 6TH, 1926.

\begin{tabular}{|c|c|c|c|c|c|c|c|c|c|c|c|c|c|c|c|c|}
\hline \multirow[b]{2}{*}{ DEPTH. } & \multicolumn{5}{|c|}{ Inshore Stations. } & \multicolumn{5}{|c|}{ Middle Stations. } & \multicolumn{5}{|c|}{ Offshore Stations. } & \multirow[b]{2}{*}{ MEAN } \\
\hline & 1 & 4 & 7 & 10 & 13 & 2 & 5 & 8 & 11 & 14 & 3 & 6 & 9 & 12 & 15 & \\
\hline $0 \mathrm{~m}$. & 8 & $11 \cdot 5$ & 12 & $14 \cdot 5$ & $24 \cdot 5$ & 7 & $12 \cdot 5$ & 12 & $23 \cdot 5$ & 17 & 9 & 9 & 12 & $12 \cdot 5$ & 17 & $13 \cdot 5$ \\
\hline $10 \mathrm{~m}$. & 12 & $11 \cdot 5$ & 12 & 21 & 24 & 10 & $12 \cdot 5$ & $11 \cdot 5$ & 23 & 2 & 8 & $11 \cdot 5$ & 12 & $12 \cdot 5$ & 13 & $14 \cdot 6$ \\
\hline $20 \mathrm{~m}$. & 16 & $12 \cdot 5$ & 10 & 20 & & 11 & 17 & 13.5 & 21 & 24 & 8 & 17 & 13.5 & 12 & 25 & 16 \\
\hline $30 \mathrm{~m}$. & 16 & $11 \cdot 5$ & 11 & 20 & & 11 & 19 & 16 & 22 & $24 \cdot 5$ & $8 \cdot 5$ & 20 & $12 \cdot 5$ & $12 \cdot 5$ & $26 \cdot 5$ & $16 \cdot 5$ \\
\hline $40 \mathrm{~m}$. & 12 & 17 & 12 & 18 & & 23 & 18 & $23 \cdot 5$ & 22 & $26 \cdot 5$ & 15 & 26 & 35.5 & 18 & 28 & $21 \cdot 0$ \\
\hline $50 \mathrm{~m}$. & & & & 22 & & 20 & 28 & $26 \cdot 5$ & 25 & & 19 & 40 & $37 \cdot 5$ & $28 \cdot 5$ & 25 & $27 \cdot 1$ \\
\hline $60 \mathrm{~m}$. & & & & & & & 26 & $24 \cdot 5$ & $31 \cdot 5$ & & 22 & 40 & $35 \cdot 5$ & 35.5 & 28 & $30 \cdot 3$ \\
\hline $70 \mathrm{~m}$. & & & & & & & & & & & 23 & 43 & $36 \cdot 5$ & $37 \cdot 5$ & 33 & $34 \cdot 6$ \\
\hline $\begin{array}{l}80 \mathrm{~m} . \\
\text { Mean }\end{array}$ & $12 \cdot 8$ & $12 \cdot 8$ & $11 \cdot 4$ & $19 \cdot 3$ & $24 \cdot 2$ & $13 \cdot 7$ & $19 \cdot 0$ & $18 \cdot 2$ & $24 \cdot 0$ & 23.4 & $\begin{array}{l}24 \cdot 5 \\
15 \cdot 3\end{array}$ & $25 \cdot 8$ & $24 \cdot 4$ & $21 \cdot 1$ & $24 \cdot 5$ & \\
\hline
\end{tabular}

The values shown in Table I are comparable to Atkins' results for September samples. A general increase with depth is recorded, the mean surface content being $13.5 \mathrm{mg} . \mathrm{P}_{2} \mathrm{O}_{5}$ per $\mathrm{m}^{3}$, while at $70 \mathrm{~m}$. the mean value is $34 \cdot 6 \mathrm{mg} . \mathrm{P}_{2} \mathrm{O}_{5}$. Summarising the conditions over the 
area investigated, it is seen that the surface values at the northern stations (10-15) are higher than the surface values at those stations to the south (see chart), while the inshore surface waters are richer in phosphate than the offshore surface waters. The mean phosphate content, in mg. $\mathrm{P}_{2} \mathrm{O}_{5}$ per $\mathrm{m}^{3}$, for the inshore, middle, and offshore stations at $0 \mathrm{~m}$., $40 \mathrm{~m}$., and $70 \mathrm{~m}$. depth is given below :--

\begin{tabular}{|c|c|c|c|}
\hline & Inshore. & Middle. & Offshore. \\
\hline $0 \mathrm{~m}$. & $14 \cdot 1$ & $14 \cdot 4$ & \\
\hline $40 \mathrm{~m}$. & $14 \cdot 7$ & $22 \cdot 0$ & $24 \cdot 5$ \\
\hline $70 \mathrm{~m}$. & - & 一 & $34 \cdot 6$ \\
\hline
\end{tabular}

\section{Results after Storage IN the Dark.}

The sample bottles used (of green glass, yielding no phosphate to distilled water) were of about 350 c.c. capacity, and, after the first determination of phosphate content, sufficient material remained in each bottle to enable a second determination to be made. Each bottle was therefore restoppered and returned to its box, and the whole stored in the dark. The second analyses were performed on November 12th to 16th, 1926, after forty days of such storage. The temperature obtaining during this period was the varying one of the laboratory.

\section{TABLE II.}

Phosphate, Mg. Per M. ${ }^{3}$, In Séptember 23Rd to 25th Samples, after FORTY DAYS' STORAGE IN THE DARK. Frtrst ANALYSED OCTOBER 4 тн то 6тн. Re-ANalysed November $12 \mathrm{TH}$ то $16 \mathrm{TH}, 1926$.

\begin{tabular}{|c|c|c|c|c|c|c|c|c|c|c|c|c|c|c|c|c|}
\hline \multirow[b]{2}{*}{ DЕРтH. } & \multicolumn{5}{|c|}{ Inshore Stations. } & \multicolumn{5}{|c|}{ Middle Stations. } & \multicolumn{5}{|c|}{ OfFshore Stations. } & \multirow[b]{2}{*}{ Mean } \\
\hline & 1 & 4 & $y$ & 10 & 13 & 2 & 5 & 8 & 11 & 14 & 3 & 6 & 9 & 12 & 15 & \\
\hline $0 \mathrm{~m}$. & - & 35 & 17 & $26 \cdot 5$ & - & - & 23 & 17 & 41 & 28.5 & - & 16 & $39 \cdot 5$ & $28 \cdot 5$ & 27 & $27 \cdot 1$ \\
\hline $10 \mathrm{~m}$. & 一 & $35 \cdot 5$ & $16 \cdot 5$ & 28 & 31 & - & 25 & 22 & $38 \cdot 5$ & 33 & - & 15 & $34 \cdot 5$ & $29 \cdot 5$ & $29 \cdot 5$ & $28 \cdot 0$ \\
\hline $20 \mathrm{~m}$. & 一 & 39 & 23 & 24 & & - & 44 & 24 & $35 \cdot 5$ & $33 \cdot 5$ & - & 17 & 43 & $27 \cdot 5$ & 30 & $31 \cdot 0$ \\
\hline $30 \mathrm{~m}$. & - & - & 23 & $30 \cdot 5$ & & - & 39 & 23.5 & 32 & 30 & $33 \cdot 5$ & 20 & 30 & $38 \cdot 5$ & $29 \cdot 5$ & $29 \cdot 9$ \\
\hline $40 \mathrm{~m}$ & - & $32 \cdot 5$ & 17 & $28 \cdot 5$ & & - & $32 \cdot 5$ & $37 \cdot 5$ & $32 \cdot 5$ & $27 \cdot 5$ & $35 \cdot 5$ & 25 & 46 & 30 & 28 & $31 \cdot 0$ \\
\hline $50 \mathrm{~m}$. & & & & $32 \cdot 5$ & & - & $39 \cdot 5$ & 36.5 & 37 & & 43 & $24 \cdot 5$ & $40 \cdot 5$ & $28 \cdot 5$ & $34 \cdot 5$ & $35 \cdot 1$ \\
\hline $60 \mathrm{~m}$. & & & & & & & 39 & $35 \cdot 5$ & $32 \cdot 5$ & & 49 & $37 \cdot 5$ & $38 \cdot 5$ & 37 & 30 & $36 \cdot 2$ \\
\hline $\begin{array}{l}70 \mathrm{~m} . \\
80 \mathrm{~m} .\end{array}$ & & & & & & & & & & & $\begin{array}{l}44 \\
40 \cdot 5\end{array}$ & 40 & $37 \cdot 5$ & $39 \cdot 5$ & $33 \cdot 5$ & $\begin{array}{c}38 \cdot 9 \\
-\end{array}$ \\
\hline Mean & - & $35 \cdot 5$ & $19 \cdot 3$ & $28 \cdot 3$ & - & - & $34 \cdot 5$ & $28 \cdot 0$ & $35 \cdot 6$ & $30 \cdot 5$ & $39 \cdot 4$ & $24 \cdot 4$ & $38 \cdot 7$ & $32 \cdot 4$ & $30 \cdot 2$ & \\
\hline
\end{tabular}

Table II gives the results of the redetermination of phosphate content after storage. A general increase in soluble phosphate is observed, the mean surface value for all stations having increased during storage from $13.5 \mathrm{mg}$. to $27 \cdot 1 \mathrm{mg} . \mathrm{P}_{2} \mathrm{O}_{5}$ per $\mathrm{m}^{3}$ The increase at $70 \mathrm{~m}$., however, is only $4.3 \mathrm{mg}$. from an original mean value of $34.6 \mathrm{mg}$. to $38.9 \mathrm{mg}$. The 
differences between the original means at the various depths and the means after storage are given below :-

$\begin{array}{lcccccccc}\text { Depth in metres } & 0 & 10 & 20 & 30 & 40 & 50 & 60 & 70 \\ \text { Mean } \mathrm{P}_{2} \mathrm{O}_{5} \text { increase } & 13 \cdot 6 & 13 \cdot 4 & 14 \cdot 6 & 13 \cdot 4 & 10 \cdot 0 & 8 \cdot 0 & 5 \cdot 9 & 4 \cdot 3\end{array}$

It is seen that the magnitude of the increase is greatest in the upper 30 metres of water, the maximum being at 20 metres.

\section{Comparative Plankton Population in the same Waters, September $14 \mathrm{TH}$ to $17 \mathrm{TH}, 1926$.}

That the upper layers of water should increase to roughly $200 \%$ of its original phosphate concentration, while the bottom waters showed only a $12 \%$ increase, pointed to the decomposition of planktonic organisms as the cause of the phenomenon. It is fortunate that data are available indicating the relative density of plankton over the same area of water on September 14th to 17th, little more than a week prior to the collection

\section{TABLE III.}

\section{Plankton Hauls, in c.c., at Stations I-IX,} SePtember 14th to $17 \mathrm{TH}, 1926$.

\begin{tabular}{|c|c|c|c|c|c|c|c|c|c|c|}
\hline DEPTH. & I & II & III & IV & V & VI & VII & VIII & IX & Mean. \\
\hline $0 \mathrm{~m}$. & 12 & 8 & 10 & 26 & 42 & 16 & 20 & 18 & 32 & $20 \cdot 4$ \\
\hline $10 \mathrm{~m}$. & 14 & 17 & 18 & 16 & 50 & 26 & 25 & 22 & 30 & $24 \cdot 2$ \\
\hline $20 \mathrm{~m}$. & 10 & 22 & 21 & 18 & 50 & 40 & 28 & 21 & 37 & $27 \cdot 4$ \\
\hline $30 \mathrm{~m}$. & 10 & 17 & 16 & 18 & 38 & 36 & 32 & 20 & 35 & $24 \cdot 6$ \\
\hline $40 \mathrm{~m}$. & 14 & 21 & 12 & 15 & 34 & 32 & 28 & 14 & 36 & $22 \cdot 9$ \\
\hline $50 \mathrm{~m}$. & 17 & 16 & 18 & 16 & 26 & 30 & & & & $20 \cdot 5$ \\
\hline $60 \mathrm{~m}$. & & & 20 & 17 & 26 & 20 & & & & $20 \cdot 7$ \\
\hline Total & 77 & 101 & 115 & 126 & 266 & $\varepsilon 00$ & 133 & 95 & 170 & \\
\hline
\end{tabular}

of the water samples (September 23rd to 25th). The positions of the nine plankton stations worked are given in the chart in Fig. 1. Catches were made at each 10 metres depth, and the figures given in Table III refer to $10-\mathrm{min}$. hauls at each depth, the catch being measured in c.c. on settling.

These values, though not absolute, are certainly comparative, and may be taken as representing roughly the distribution of plankton over the area at the time in question. The mean hauls at each depth are given in the Table, and it will be seen that the maximum appears at 20 metres, the mean haul being $27 \cdot 4$ c.c. 


\section{Relation between Mean Phosphate Increase and Mean Plankton Haul.}

Considering the mean increase at each depth of soluble phosphate on storage and the mean plankton haul, a close relation is observed. The graph in Fig. 2 gives these values plotted according to depth.

Both curves show a maximum at 20 metres depth, and from this point down to 50 metres they run almost parallel. A discrepancy is observed

Fra. 2.

\section{DEPTH}

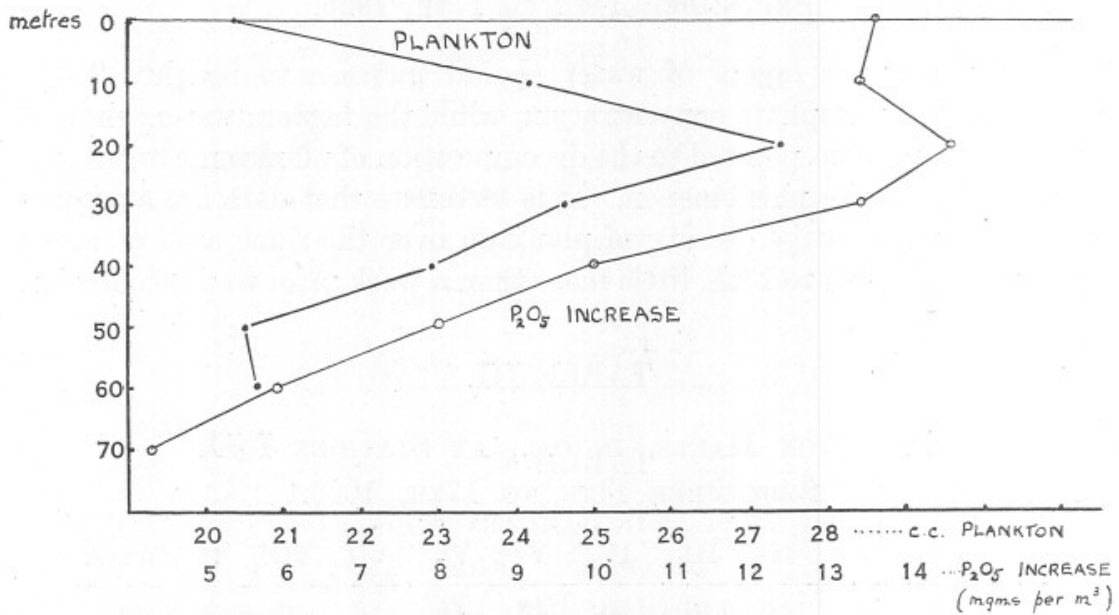

FIG. 2.-Mean plankton haul and mean increase in soluble phosphate on storage.

f Plankton collected, Sept. 14-17, 1926.

(Water samples ,, Sept. 23-25, 1926.

in the surface and 10 metres regions, but this is very feasibly explained by the coarseness of the mesh of the plankton nets used (23 strands per cm.). This mesh is not sufficiently fine to include the bulk of the phyto-plankton, which naturally would be most abundant in the upper layers of water, and which would undoubtedly affect the phosphate content of the water samples on storage. In view of this, the plankton values for the surface layers used in the compilation of the graph in Fig. 2 probably do not represent the true bulk of planktonic organisms inhabiting these regions.

\section{Storage of Winter Samples.}

A second series of experiments was conducted along exactly similar lines as described above, upon samples collected on January 6th to 8th, 1927. The first analyses were made on January 13th (Table IV), and 
the second analyses on March 19th to 21st, after a period of sixty-five days' storage in the dark (Table V). The fifteen stations on the chart in Fig. 1 were not all visited, owing to the inclemency of the weather, and only ten points were sampled.

\section{TABLE IV.}

Phosphate Content, Mg. $\mathbf{P}_{2} \mathbf{O}_{5}$ PeR M. ${ }^{3}$, at Stations 1-12. Samples COllected January 6th to 8Th, 1927. Analysed January $13 \mathrm{TH}, 1927$.

\begin{tabular}{|c|c|c|c|c|c|c|c|c|c|c|c|}
\hline \multirow[b]{2}{*}{ DЕРтн. } & \multicolumn{3}{|c|}{$\begin{array}{l}\text { INSHORE } \\
\text { STATIONS. }\end{array}$} & \multicolumn{3}{|c|}{$\begin{array}{l}\text { Midmle } \\
\text { Stations. }\end{array}$} & \multicolumn{4}{|c|}{$\begin{array}{l}\text { OfFSHORE } \\
\text { Stations. }\end{array}$} & \multirow[b]{2}{*}{ Mean. } \\
\hline & 1 & 7 & 10 & 2 & 8 & 11 & 3 & 6 & 9 & 12 & \\
\hline $0 \mathrm{~m}$. & 18 & 22 & 23 & $15 \cdot 5$ & $23 \cdot 5$ & 23 & 18 & 20 & 22 & 22 & $20 \cdot 7$ \\
\hline $10 \mathrm{~m}$. & $18 \cdot 5$ & 23 & 25 & $17 \cdot 5$ & $24 \cdot 5$ & 24 & $17 \cdot 5$ & - & $27 \cdot 5$ & 22 & $22 \cdot 2$ \\
\hline $20 \mathrm{~m}$. & 18 & 23 & $24 \cdot 5$ & 18 & $23 \cdot 5$ & $21 \cdot 5$ & 16 & $21 \cdot 5$ & 25 & $24 \cdot 5$ & $21 \cdot 5$ \\
\hline $30 \mathrm{~m}$. & 19 & $22 \cdot 5$ & 25 & 17 & 25 & 22 & 16 & - & 23 & 25 & $21 \cdot 6$ \\
\hline $40 \mathrm{~m}$. & $17 \cdot 5$ & $24 \cdot 5$ & 25 & 18 & 23 & 21 & 19 & 20 & 22 & $24 \cdot 5$ & $21 \cdot 4$ \\
\hline $50 \mathrm{~m}$. & & & $25 \cdot 5$ & 19 & 27 & 23 & $17 \cdot 5$ & - & $24 \cdot 5$ & 25 & $23 \cdot 1$ \\
\hline $60 \mathrm{~m}$. & & & & & & 23 & 18 & $21 \cdot 5$ & 24 & 21 & $21 \cdot 5$ \\
\hline $70 \mathrm{~m}$. & & & & & & & 19 & - & $25 \cdot 5$ & & $22 \cdot 3$ \\
\hline Mean & $18 \cdot 2$ & $23-0$ & $24 \cdot 7$ & $17 \cdot 5$ & $24 \cdot 4$ & $22 \cdot 5$ & $17 \cdot 6$ & $20 \cdot 7$ & $24 \cdot 2$ & $23 \cdot 4$ & \\
\hline
\end{tabular}

TABLE V.

Phosphate, Mg. $P_{2} \mathrm{O}_{5}$ Per M. ${ }^{3}$, IN Jandary Samples, after siXty-Five DAys' storage in the Dark. First analysed JanUary 13. Re-Analysed MaRch 19Th to 21st, 1927.

\begin{tabular}{|c|c|c|c|c|c|c|c|c|c|c|c|}
\hline \multirow[b]{2}{*}{ DEPTH. } & \multicolumn{3}{|c|}{$\begin{array}{l}\text { InsHoRe } \\
\text { Stations. }\end{array}$} & \multicolumn{3}{|c|}{$\begin{array}{c}\text { Mrdden } \\
\text { Stations. }\end{array}$} & \multicolumn{4}{|c|}{$\begin{array}{l}\text { OfFSHORE } \\
\text { StATIONS. }\end{array}$} & \multirow[b]{2}{*}{ Mean. } \\
\hline & 1 & $y$ & 10 & 2 & 8 & 11 & 3 & 6 & 9 & 12 & \\
\hline $0 \mathrm{~m}$. & 43 & 41 & 27 & $38 \cdot 5$ & $42 \cdot 5$ & 41 & $45 \cdot 5$ & $47 \cdot 5$ & 42 & 36 & $40 \cdot 4$ \\
\hline $10 \mathrm{~m}$. & $42 \cdot 5$ & $32 \cdot 5$ & 36 & $41 \cdot 5$ & 33 & 36 & 45 & - & 98 & 44 & $45 \cdot 4$ \\
\hline $20 \mathrm{~m}$. & 45 & 39 & 40 & 59 & $33 \cdot 5$ & 39 & 45 & $47 \cdot 5$ & 41 & 40.5 & $42 \cdot 9$ \\
\hline $30 \mathrm{~m}$. & $62 \cdot 5$ & 50 & $35 \cdot 5$ & 45 & 36 & 43 & $42 \cdot 5$ & - & 38 & $39 \cdot 5$ & $43 \cdot 6$ \\
\hline $40 \mathrm{~m}$. & 40 & 45 & $35 \cdot 5$ & 45 & 36 & 44 & 44 & 46 & 39 & 41 & $41 \cdot 5$ \\
\hline $50 \mathrm{~m}$. & & & 31 & $52 \cdot 5$ & $38 \cdot 5$ & 32 & 43 & - & 37 & $41 \cdot 5$ & $39 \cdot 3$ \\
\hline $60 \mathrm{~m}$. & & & & & & 38 & 50 & 46 & 29 & 38 & $40 \cdot 2$ \\
\hline $70 \mathrm{~m}$. & & & & & & & $45 \cdot 5$ & - & $31 \cdot 5$ & & $38 \cdot 5$ \\
\hline Mean & $46 \cdot 6$ & $41 \cdot 5$ & $34 \cdot 2$ & $46 \cdot 9$ & $36 \cdot 6$ & $39 \cdot 0$ & $45 \cdot 0$ & $46 \cdot 7$ & $44 \cdot 4$ & $40 \cdot 1$ & \\
\hline
\end{tabular}

In the following table the differences between the mean values at each depth in Tables IV and V are given, and show the increases which occurred at various depths as a result of the storage treatment:-

Depth, metres

Mean $\mathrm{P}_{2} \mathrm{O}_{5}$, Jar. 13

Mean $\mathrm{P}_{2} \mathrm{O}_{5}$, Mar. 19-21

Increase, $\mathrm{P}_{2} \mathrm{O}_{5} \mathrm{mg}$. per $\mathrm{m}^{3}$

$\begin{array}{cccccccc}0 & 10 & 20 & 30 & 40 & 50 & 60 & 70 \\ 20 \cdot 7 & 22 \cdot 2 & 21 \cdot 5 & 21 \cdot 6 & 21 \cdot 4 & 23 \cdot 1 & 21 \cdot 5 & 22 \cdot 3 \\ 40 \cdot 4 & 45 \cdot 4 & 42 \cdot 9 & 43 \cdot 6 & 41 \cdot 5 & 39 \cdot 3 & 40 \cdot 2 & 38 \cdot 5 \\ 19 \cdot 7 & 23 \cdot 2 & 21 \cdot 4 & 22 \cdot 0 & 20 \cdot 1 & 16 \cdot 2 & 18 \cdot 7 & 15 \cdot 2\end{array}$


It will be seen on comparison with the September storage values that the increases above are of a higher order than experienced previously, doubtless due to the longer period of storage, namely, sixty-five days as compared to forty days. On the other hand, the temperature during the later series of experiments was generally lower, and one would assume the plankton population to be less dense in January than in September. It is therefore somewhat surprising that the January samples should give such relatively large increments. The greatest increase is found in the samples from $10 \mathrm{~m}$. depth, being $23 \cdot 2 \mathrm{mg} . \mathrm{P}_{2} \mathrm{O}_{5}$ per $\mathrm{m}^{3}$, while the minimum increase is observed in the samples from deeper water, $70 \mathrm{~m}$. indicating an increase of $15 \cdot 2 \mathrm{mg}$. on the original phosphate content. The upper $40 \mathrm{~m}$. of water again gives the largest increases, confirming the results of the September samples.

It is interesting to note that those stations which originally indicated the lowest phosphate content (see Table IV), gave the greatest increases in soluble phosphate on storage. Thus Stations 1, 2, and 3 showed initial mean values for each column of water of $18 \cdot 2,17 \cdot 5$, and $17 \cdot 6 \mathrm{mg}$. $\mathrm{P}_{2} \mathrm{O}_{5}$ per $\mathrm{m}^{3}$ respectively, and after storage (see Table $\mathrm{V}$ ) these mean values became $46 \cdot 6,46.9$, and $45 \cdot 0 \mathrm{mg}$. Conversely, those stations indicating the greatest phosphate content originally gave much smaller increases, e.g. Stations 10, 8, 11, 12. This may be interpreted by assuming that where low values for phosphate were found, the plankton was numerous, and where the phosphate was high the plankton was sparse.

No plankton figures are available for the area investigated for the month of January.

\section{SUMMARY.}

1. The alteration in soluble phosphate content of untreated sea-water during storage is governed by the conditions of storage - a strong light, favourable to growth, produces a decrease, while darkness, unfavourable to growth, produces an increase.

2. Samples from the surface layers of the sea give greater increases on storage in the dark than samples from deeper water, the extent of the increase being conditioned by the number and quantity of planktonic organisms included in the water sample.

\section{NOTE.}

A decrease in soluble phosphate was observed by Atkins (1925, Vol. XIII, No. 3, p. 717) in sea-water samples sent out as blanks on a voyage between Liverpool and Colombo. From this decrease, Atkins formulated a factor for the correction of the phosphate values of sur- 
face samples collected during the voyage, though this correction was, " it must be admitted, of doubtful validity."

The light conditions during the storage period of the blanks are not given, though it is assumed that the case of boxes was stored in the dark. Storage in the dark, therefore, does not always produce an increase in phosphate, though such was the case in the 140 odd samples of North Sea water described in this paper.

\section{REFERENCES.}

Atkins, W. R. G. 1923. The phosphate content of fresh and salt waters in its relationship to the growth of algal plankton. Journ. Mar. Biol. Assoc., Vol. XIII, No. 1, p. 124.

Atkins, W. R. G. 1925. Seasonal changes in the phosphate content of sea-water in relation to the growth of the algal plankton during 1923 and 1924. Loc. cit., Vol. XIII, No. 3, p. 701.

Atkins, W. R. G. 1926. The phosphate content of sea-water in relation to the growth of algal plankton. Part III. Loc. cit., Vol. XIV, No. 2, p. 448.

Matthews, D. J. 1917. On the amount of phosphoric acid in the seawater off Plymouth Sound. Part II. Loc cit., Vol. XI, No. 2, p. 251.

Denigès, G. 1921. Détermination quantitative des plus faibles quantités de phosphates dans les produits biologiques per la méthode céruléomolybdique. C.R. Soc. Biol., Paris, 84, No. 17, pp. 875-877. 
